\title{
LAND CONSOLIDATION IN CRISIS MANAGEMENT
}

\author{
Agnieszka Trystula, Jadwiga Konieczna \\ University of Warmia and Mazury in Olsztyn, Poland \\ agnieszka.trystula@uwm.edu.pl, jadwiga.konieczna@uwm.edu.pl
}

\begin{abstract}
Socio-economic development, public safety of local communities and environmental protection are the major pillars of the concept of sustainable development of rural areas in Europe. Land consolidation is a complex and time-consuming undertaking, which requires high expenditures, yet it plays an important role in the policy of sustainable and multi-functional development. The rapid climate change observed in recent years, resulting in a number of unusual weather conditions, has also had an effect on the directions of land consolidation development. Natural hazards (e.g., floods, fires, and landslides) are an inseparable element, which needs to be taken into account in the designing of rural space. Due to access to modern analytical technologies and the visualisation of information on a particular area, in combination with the procedure of land consolidation, we have a tool, which also allows us to implement activities in the field of crisis management, particularly at the stage of preventing a crisis, as well as at the stage associated with the restoration of the situation prevailing prior to the hazard occurrence (restoration of damages). The aim of the study is to present the role and significance of the procedure of land consolidation in supporting efforts to prepare for the occurrence of a crisis (inter alia the indication of the location of areas designated for flood protection investment projects in the land consolidation plan) as well as to remove its tragic consequences (inter alia the indication of the location of post-fire areas designated for reforestation in the land consolidation plan).
\end{abstract}

Keywords: land consolidation, crisis management.

\section{Introduction}

Land consolidation is one of the most important elements for helping to solve the structural problems in agriculture and agricultural production [1].

The rapid socio-economic changes and the climate change observed in the recent years, as well as the access to modern technologies and innovative solutions are factors which have also had an effect on the directions of land consolidation development. Until now, the traditional consolidation procedure used to be targeted, in accordance with applicable laws, at increasing the profitability of Polish agriculture. However, the above-mentioned changes contributed to the transformation of land consolidations into a modern tool which is not only focused on the productivity of farms but also on, inter alia, improving the quality of life, searching for non-agricultural functions of rural areas, and ensuring the security of the local community [2].

The aim of the study is to present the role and significance of the procedure of land consolidation in supporting efforts to prepare for the occurrence of a crisis (inter alia the indication of the location of areas designated for flood protection investment projects in the land consolidation plan) as well as to remove its tragic consequences (inter alia the indication of the location of post-fire areas designated for reforestation in the land consolidation plan).

\section{Crisis management in the system for security of rural area communities}

Before considering crisis management, it should be emphasised that it is an integral part of management per se, and that we are talking about management under pressure and at risk. It involves reducing tensions and preventing an escalation of adverse events or difficult situations, and restoration of the normal state or maintaining such a state despite the appearance of symptoms of a crisis. Each state, including Poland, considers maintaining a high security level through maintaining adequate preparedness for preventing any external and internal hazard to be one of its fundamental duties. It will be implemented through, inter alia, the crisis management system [3].

Security is the contemporary measure of chances of the existence, survival and development of a state, a society and its citizens [4]. It is a fundamental value for both an individual and a social community. Its main aspects include the lack of a sense of danger, a sense of certainty and the freedom of development. Security is the basis of the operation of a country and has an overriding role in activities of the state [5].

Crisis management is a form of activity of public administration authorities, involving both the prevention of crises and the continuous preparation for taking control of crises through implementing 
previously planned measures, responding in the event of a crisis, removing its consequences and the earliest possible reconstruction of destroyed or damaged infrastructure, which is significant from the perspective of the functioning of the state, its administrative structures and society [6].

Crisis management is not only carried out by public administration authorities, as various organisations, institutions and the local community are also involved. Crisis management is a rapidly developing field of knowledge. It requires constant adjustment of the capacities to the ever-changing state of security in order to maintain the capacity to respond. The dynamism of crises is a source of constant changes as regards the continuous improvement of mechanisms of activities, procedures, and principles of cooperation [7].

The crisis management process involves 4 basic stages of operation:

1. The crisis prevention stage during which a series of, inter alia, investment projects aimed at reducing the risk of hazard occurrence, are implemented (e.g., projects involving the modernisation or construction of flood protection facilities, such as river embankments, holding tanks, flood channels, and detention basins, or associated with fire protection, such as firebreaks separating forested areas from buildings and road infrastructure). The prevention stage also involves drawing up plans for the development of areas at risk of flood, mass ground movements or fires, etc.

2. The stage of preparation for a crisis occurrence involves, inter alia, the development of databases of areas at risk of a hazard occurrence, e.g., a register of landslides, maps of fire hazard and maps of flood hazard.

3. The stage of responding to crises involves, inter alia, warning, alerting emergency services, evacuation of people, animals and property and reducing secondary damage and losses.

4. The reconstruction stage involves providing assistance to casualties as well as the reconstruction of protection facilities, buildings, technical infrastructure and the restoration of functional properties of agricultural areas destroyed by flood [2].

\section{The role of land consolidations in the activities preventing the occurrence of a crisis and in} activities aimed at the restoration of damage - results and discussion

The main aim of research was to present the significant role of land consolidation in crisis management. The research applied the following methods: analysis and synthesis of the literature and land consolidation documentations, survey research.

For many parts of Europe, there are growing concerns with the impacts of natural hazards. This is related to the loss of life as well as their major costs, both financial and non financial [8]. In Europe, various types of natural hazards occur, including inter alia floods, mass ground movements and forest fires [9].

Floods are primarily caused by intense and heavy rainfalls, thaws and ice-jams which, in combination with human interference in the environment such as housing developments in flood hazard zones, or intensive agricultural activities carried out within such zones, may result in the intensification of their tragic socio-economic consequences. Landslides are another natural hazard resulting from mass ground movement i.e. movement of rock or ground masses under the influence of gravity [10]. Landslide movements are caused by intense or prolonged rainfalls in combination with floods and increased lateral erosion of rivers as well as the rapid melting of snow-cover in the early spring [11].

Forest fires are the most important threat to forest and wooded area in Europe. Fires have caused extensive damage in recent years, leading to loss of human lives, affecting human health, burning properties, infrastructures and business and causing extensive environmental damage in forest and agriculture areas [12].

One of the stages of consolidation works is the development of assumptions for the design of land consolidation, which must be preceded by a number of studies and analyses concerning the conditions of agricultural production, agricultural farms, natural conditions, and landscape as well as cultural and historical values. The aim of these analyses and studies is to determine the economic, social, environmental, cultural, and recreational potential of a consolidation object.

As it is well known, the assumptions for a consolidation design concern inter alia: 
- spatial organisation of agricultural farms, including, e.g., the improvement of areal structure of farms, reasonable shaping of the land layout, the development of agricultural transport road network and the adjustment of property boundaries to the system of land drainage facilities and road networks;

- design of the natural landscape, including inter alia afforestation and the introduction of woodlots;

- improvement of hydrological conditions and water management, including basic land drainage systems, specific land drainage system and the construction of water reservoirs;

- changes to the land use structure.

In order for land consolidations to become a significant instrument supporting measures preventing the occurrence of a crisis, it is necessary to indicate, in the assumptions to the consolidation design, the areas which should be designated for investment projects associated with the following:

1. Flood protection, pinpointing the location of areas:

- meant for the construction of flood banks, drainage ditches, water storage reservoirs;

- meant to carry overflow in the case of a propagating flood wave in order to protect built-up areas;

- outside of an area subject to flooding in order to relocate buildings away from the endangered zone;

- subject to the risk of flooding, along with their proper natural and agricultural development.

2. Fire protection - the indication of the location of areas designated for:

- firebreaks;

- fire protection lookout points (fire towers);

- operational landing areas (rescue and fire-fighting flights);

- artificial water reservoirs - fire extinguishing water take-off points;

- forest access roads - accessways for firefighters.

3. Landslide mitigation, pinpointing the location of areas:

- outside of an area subject to slope movement, in order to relocate buildings away from the endangered zone;

- indicated for complete or limited exclusion from development within a landslide zone.

However, in order for the quality of the land consolidation operations to considerably affect, among other things, the creation of strong and profitable agricultural farms, enabling the availability of access roads and other elements of technical infrastructure while retaining the current landscape value and biological diversity, as well as the protection of rural areas against the disastrous effects of natural hazards, the people conducting the land consolidation must be provided with unhindered and quick access not only to current and skilfully selected data but also to the tools and solutions enabling spatial analyses (2D, 3D, etc.) along with a visualisation of the results of those analyses [13].

\section{The role of land consolidations in activities aimed at the restoration of damage}

The final stage of crisis management process is the reconstruction stage which involves controlling crises through taking planned measures, minimisation of losses and restoration of damage. This period involves, inter alia, taking measures aimed at reconstruction (restoration) of:

- residential, utility and public buildings;

- destroyed flood protection and fire protection facilities;

- communication infrastructure;

- critical infrastructure facilities and elements (e.g. energy supply, information and communication networks, communication, food supply, water supply, health care, transport, and rescue);

- production potential of agricultural areas and forest areas damaged by flood.

All orders issued during the reconstruction stage, related to the re-development of areas destroyed by flood, mass ground movements, or fires should also be taken into account in the design of consolidation assumptions and in the design of post-consolidation development, which is an integral 
part of the consolidation procedure. At the stage of preparing assumptions for the consolidation design, it is possible to indicate the following:

1. Post-flood areas, inter alia those:

- designated for the reconstruction of residual, utility and public buildings,

- requiring the restoration of their (agricultural and forest) production potential - reclamation of post-flood areas,

- designated for the reconstruction of flood protection facilities,

- designated for flooded areas to be used, e.g., as recreational zones.

2. Post-fire areas, inter alia those:

- requiring the restoration of their production potential - reclamation of burned areas;

- designated for afforestation;

- designated for the reconstruction of fire protection facilities;

- designated for the reconstruction of facilities used for the purposes of forest management.

3. Post-landslide areas, inter alia those:

- requiring the restoration of their (agricultural and forest) production potential - reclamation;

- indicated to be excluded from development.

To conclude, land consolidation is becoming an important element of crisis management in rural areas, especially during the preparatory phase for a crisis event, when actions are taken aimed at minimising the threat, for example, by the construction of anti-flood devices, choosing land for antifire belts or appropriate development of land endangered with mass movements, the location of which and the method of use can be established at the stage of developing principles for a land consolidation project [14].

\section{Conclusions}

Floods, forest fires and landslides are natural hazards, which bring about unexpected and undesirable changes to the environment, which have an adverse effect on both the human and their property. Therefore, efforts should be made to expand the scope of consolidation works shaping, in an optimal manner, spaces which are potentially at risk, e.g., of floods, to include the needs and requirements related to the prevention and protection against such extreme natural events.

Traditional land consolidation procedure aims at improving the conditions of farming and forest management, emphasising the agricultural function of rural area. The social and economic transformations, climate change and technological progress have changed land consolidation into a modern tool, which not only improves the agrarian structure, the transport systems in agriculture or land improvement devices in the regions where agricultural business activities are conducted, but it also creates development opportunities for the non-agricultural function of rural areas. Land consolidation is becoming an important element of crisis management in rural areas.

\section{References}

1. Thomas J. Property rights, land fragmentation and the emerging structure of agriculture in Central and Eastern European countries. Journal of Agricultural and Development Economics 2, 2006, pp. 225-275.

2. Trystuła A., Konieczna J. The role of land consolidation in performing tasks the scope of protection from the effects of natural hazards. Bariery i stumulanty rozwoju obszarów wiejskich. Olsztyn 2014, p. 50-61.

3. Lidwa W. at al. Crisis management. Warszawa: Akademia Obrony Narodowej, 2010.

4. Kunikowski J. Słownik terminów z zakresu wiedzy i edukacji dla bezpieczeństwa. Bydgoszcz: Wydawnictwo Akademii Bydgoskiej' 2005.

5. Sienkiewicz - Małyjurek K. Zarządzanie bezpieczeństwem w samorządach lokalnych. Seria SWSPIZ w Łodzi: Przedsiębiorczość i Zarządzanie, vol. X/8/ 2009.

6. Juchnicki M., Nowakowski Z., Protasowicki I. System zarządzania kryzysowego Unii Europejskiej. Available at: 
7. https://www.researchgate.net/profile/Igor_Protasowicki/publication/263570707_System_zarzadza nia_kryzysowego_Unii_Europejskiej/links/00b7d53b4196d7ccf7000000.pdf

8. Sienkiewicz - Małyjurek K. Problemy organizacyjne zarządzania kryzysowego w samorządach. Zeszyty Naukowe Politechniki Śląskiej 2011 Seria: ORGANIZACJA I ZARZĄDZANIE z. 59.

9. Territorial Dynamics in Europe Natural Hazards and Climate Change in European Regions. Territorial Observation No.7, May 2013. The ESPON Programme. .

10. Report on the progress in implementation of the Floods Directive Accompanying the document Communication From The Commission To The European Parliament And The Council. The Water Framework Directive and the Floods Directive: Actions towards the 'good status' of EU water and to reduce flood risks. European Commission 2015.

11. Cała M. Osuwiska w Polsce i na świecie - Geotechnika szuka sposobów przeciwdziałania szkodliwym skutkom przemieszczeń zboczy. Nowoczesne Budownictwo Inżynieryjne 3(24)/2010. Kraków.

12. Grabowski D., Rączkowski W. Geozagrożenia w Polsce - osuwiska. Dodatek lobbingowy do „Rzeczpospolitej” / 2007. Warszawa.

13. Bassi S., Kettunen M. Forest fires: causes and contributing factors in Europe. Policy Department, Economic and Scientific Policy. London.

14. Trystuła A., Geovisualisation applied in the construction of rural space, Infrastructure and Ecology of rural areas vol. Nr 2/III/2013, Poland 2013. 